\title{
ORGANISING REGIONS: SPATIAL PLANNING AND TERRITORIAL GOVERNANCE PRACTICES IN TWO SWEDISH REGIONS
}

\author{
Lukas Smas $^{1}$ (D) , Johannes Lidmo² (D) \\ ${ }^{1}$ Department of Human Geography, Stockholm University \\ SE-106 91 Stockholm: Sweden \\ lukas.smas@humangeo.su.se \\ 2 Nordregio \\ Box 1658, SE-111 86 Stockholm: Sweden \\ johannes.lidmo@nordregio.org
}

\begin{abstract}
In some European countries, sub-national regions are important geographical arenas for spatial planning. However, in Sweden, statutory regional planning is rather limited and the regional level is often described as having a weak position in the spatial planning system. In this article, we investigate territorial governance practices in two Swedish regions, with a focus on their interaction with the EU and the national level, and with the local level, as well as how these regions function as organisations and arenas for coordination of different policy fields. The study is based on semi-structured expert interviews and document analysis. The results show that spatial planning is practised both through statutory planning and soft planning approaches, and that these practices in different ways coordinate sectoral policies i.e. transport infrastructure and regional development. Both cases also illustrate difficulties not only of external coordination between different institutions and policy fields but also internally within organisations. It is also highlighted that spatial planning at the regional level focuses on coordinating actors and policy fields but that spatial planning is also an instrument to implement regional policies. In conclusion, it is argued that the organisation and territorial governance practices within a given institutional arrangement and the perception of spatial planning are crucial in determining how regions might function as multi-level coordination actors and policy arenas within spatial planning.
\end{abstract}

Keywords: multi-level coordination, policy fields, regions, spatial planning, territorial governance.

\section{Introduction}

In many European countries, regions are important government institutions and policy arenas, not least in terms of territorial governance and cohesion policy but also for spatial planning. However, the significance and practical relevance of regional planning (or spatial planning at the regional level) varies significantly across Europe. For example, in the Nordic countries there are divergent trajectories regarding the role and function of the sub-national regional level within territorial governance because of shifting political conditions for spatial planning and changes in the government system (e.g. Galland 2012; Røiseland et al. 2015; Schmitt \& Smas 2019). In this paper, we inves- 
tigate the institutional context and organisation of regional planning in Sweden and consider how different forms of spatial planning are practised through the territorial governance of two Swedish regions. Also, the relationship between cohesion policy and spatial planning systems is analysed since the notions of soft spaces and soft planning have been proposed as ways to comprehend how European spatial policies are fitted into national planning systems (Purkarthofer 2016).

Regional planning or spatial planning at regional level might be understood (or conceptualised) as a sub-national mode of horizontal and vertical coordination to integrate various issues, policy fields or sectoral based interests (e.g. Neuman 2007; Neuman \& Zonneveld 2018). The (city-) regional level is often recognised as an adequate scale for many contemporary problems (Rodríguez-Pose 2008; Hanssen et al. 2013), but in practice (in realpolitik) the regions are a marginal political level in Sweden and the Nordic countries (Hammarlund 2004; Lidström 2013). Consequently, spatial planning at the regional level is also rather weak in Sweden and the Nordic countries, but this also provides opportunities for policy experimentation, which is evident across the Nordic countries (Røiseland et al. 2015; Schmitt \& Smas 2019). In relation to this, a potentially key role for the regional level in for example Sweden (and the other Nordic countries) within the current condition of multi-level governance is to be "a multi-level coordination actor" (Hanssen et al. 2013) where a key issue is "policy-integration" (Hovik \& Stokke 2007). To put it differently, regions have in principle the potential of being key arenas for territorial governance practices to coordinate institutions and policy fields, to mobilise a wide arrange of stakeholders, to adapt to changing contexts, and to facilitate place-based development (van Well \& Schmitt 2016).

In this article we investigate the territorial governance practices in the two Swedish regions of Stockholm and Östergötland (Fig. 1) with a focus on the vertical position of the regions from the EU to the local level, and sectoral integration or coordination between spatial planning and other policy fields, i.e. transport infrastructure and regional development. The article is a result of the ESPON project COMPASS: Comparative Analysis of Territorial Governance and Spatial Planning Systems in Europe, which aimed to compare territorial governance practices and spatial planning systems and policies across Europe. In the ESPON COMPASS project, territorial governance was conceptualised as comprising "the institutions that assist in active cooperation across government, market and civil society actors to coordinate decision-making and actions that have an impact on the quality of places and their development" (ESPON COMPASS 2018: viii). While "spatial planning systems are the ensemble of institutions that are used to mediate competition over the use of land and property, to allocate rights of development, to regulate change and to promote preferred spatial and urban form" (ESPON COMPASS 2018: viii). From this perspective, spatial planning is viewed and defined as a policy field in its own right, separate from policy fields such as transport infrastructure and regional development. Furthermore, it is important to recognise that the focus of the project was on the institutional structure of the spatial planning system and the practice of territorial governance.

The two regions were selected because they represent two different approaches to spatial planning at the regional level in Sweden, and their selection provides an opportunity to explore how territorial governance is practised and organised in different ways with the same institutional structure and spatial planning system. Empirically the case study is based on semi-structured expert interviews and document analysis. The latter included reviews of planning and policy documents connecting cohesion policy and other sector policies (transport infrastructure and regional development) with spatial planning. The former included semi-structured interviews with representatives from national a nd regional authorities. The interviews and document analysis were conducted during the autumn of 2017. 


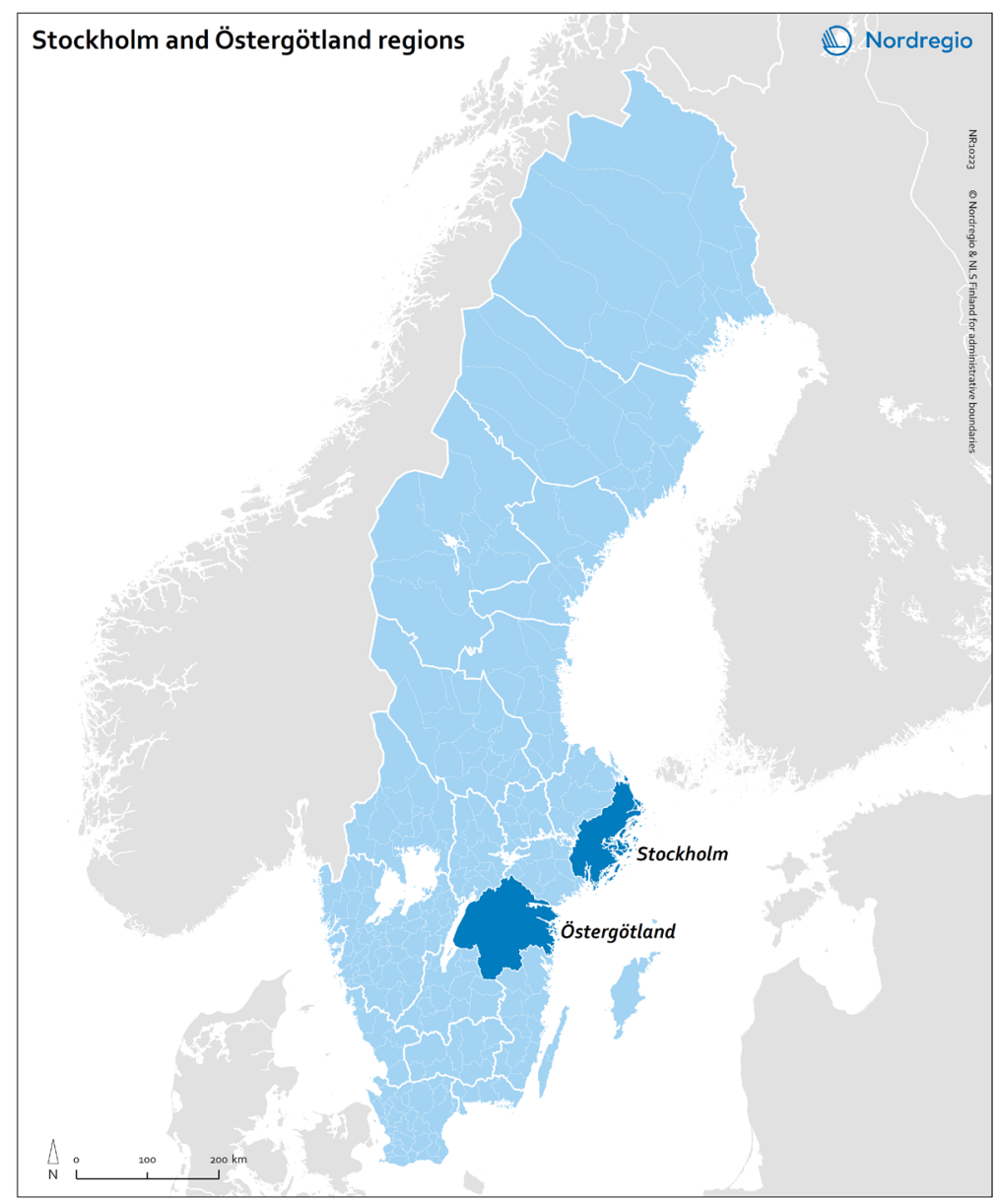

Figure 1. Map of Swedish regions and the case study regions Source: Nordregio (Designer/Cartographer Julien Grunfelder).

\section{The organisation of spatial planning in Sweden}

In a European context of administrative and legal families the Swedish planning system has often been described as comprehensive because of the welfare state tradition and the focus on coordination of sectors through a spatial perspective, and because of the hierarchal formal and integrated public planning system (CEC 1997; Nadin \& Stead 2008). However, in Sweden, statutory regional planning is limited and the regional level is often described as having a rather weak position in between national (sectoral) authorities and self-governing local municipalities (Newman \& Thornley 1996; Smas \& Schmitt 2018). 
Spatial planning in Sweden is to a large degree equated with municipal planning. The Swedish municipalities have a sort of planning monopoly, since they have the mandate to decide what gets built where through regulatory detailed development plans and by granting (or not granting) building permits without any obligatory need of coordination with upper level plans or programmes. The compulsory municipal comprehensive plans outline the public interests, which often include both strategic development policies as well as land use guidelines, but which are not legally binding. Planning at this local level can be characterised as relatively comprehensive due to the numerous tasks related to the development and provision of public services that are under the aegis of municipalities. In addition, most of the 290 Swedish municipalities cover comparatively large areas, which are often of the size of planning regions in other countries (such as Germany, Italy or the Netherlands). This fact further demonstrates that municipal planning also deals with issues of more regional scope, such as urban-rural interactions, infrastructure provision, and ecosystem services. Last but not least, the so-called municipal planning monopoly is further enhanced by a strong local municipal autonomy through direct income taxes.

As in many other European countries, planning at the national level is mainly of a guiding character. It becomes explicit and tangible in politics and society when for example new transport linkages of national interest are being planned or when changes are being undertaken within the legal frameworks for planning (Schmitt 2015). The Planning and Building Act (SFS 2010:900), which in combination with the Swedish Environmental Code (SFS 1998:808) frame the Swedish planning system, was revised in 2010 in order to create a more efficient planning system and to underline the importance of strategic spatial planning.

There are regulatory national provisions specifying geographic areas of national interest, but there is no overarching statutory strategic or visionary spatial planning document for Sweden. National state agencies, such as the Swedish Transport Administration can thus designate areas of national interest. Both the mandate to designate such areas and the areas themselves have direct implications for local and regional planning. It should however be noted that Sweden has rather small national ministries with limited mandates and executive power in comparison with many other countries, and autonomous government agencies (Fig. 2). An agency in this sense is a statutory public organisation with some degree of autonomy from the ministry or department to which it is closely related but structurally separated from (Pollitt et al. 2005). However, there is a strong relation in Sweden between the central government and the regions through the national state agency at the regional level - the county administrative boards (Böhme 2002).

In the Swedish government system there are two main sub-national regional authorities (see Fig. 2). The first is the county administrative board, which is a national state agency that represents the national level at the region level and acts as a regional governing and coordinating agency for the state. Then there are the county councils, which are directly elected regional bodies responsible for health care and public transport. From January 2019, all county councils have the responsibility for regional development policy and consequently have been renamed as Regions. This will harmonise the sub-national institutional structure, which has been a complex institutional web in which different types of authorities have been responsible for regional development. For instance, in some regions the responsibility for regional development policy has been the responsibility for the directly elected county council. In other regions, inter-municipal (including the county councils) cooperation agencies have been tasked with regional development policy (which used to be the case in Östergötland). While in other regions, the county administrative board has been responsible for the regional development policy (which used to be the case in Stockholm). The division of responsibilities between the national state agency at regional level and the regional county 
councils will probably be clearer in the future. However, the relations and coordination between different policy fields such as spatial planning, regional development and transport infrastructure are also determined by territorial governance practices, and dependent on how regional planning is actually organised in the regions. Furthermore, each of these policy fields is guided by different legislation and is the responsibility for different national agencies and ministries, as will be discussed below.

The Parlament, the Government, ministries
Government agencies
Subnational County Administrative Boards County Councils
Local
Municipalities

Figure 2. Swedish government institutions Source: authors' own elaboration.

The main tasks for the Regions (former county councils) in Sweden are, as mentioned above, health care, public transport and regional development. With regard to the latter the sub-national authorities responsible for regional development are commissioned to lead and develop regional sustainable growth policies in accordance with the Regional Growth Ordinance (SFS 2007:713). The responsible regional authorities are tasked with drafting the regional development programmes and strategies, and coordinating their implementation. The regional development programmes and strategies should also guide local strategies in municipalities, related regional strategies and development processes. This was reinforced by an amendment to the Planning and Building Act in 2011, which stressed that the municipal comprehensive plan should take national and regional objectives into account (Boverket 2011). Another focus is on the implementation and management of EU cohesion policy. Thus, from a legislative structural perspective, spatial planning and regional development are two distinct fields

\section{Spatial planning and two other policy fields}

According to The Swedish National Board of Housing, Building and Planning there are 21 different policy fields that are of importance for spatial planning in Sweden, with 28 different national authorities responsible for the around 100 different national goals relevant for spatial planning (Boverket 2011: 17). The local and regional levels are emphasised as important to concretise these goals and for implementing them, which however is difficult because of the different character of the goals but also because they often derive from the national budget proposals (Boverket 2014: 10). Furthermore, there are, as mentioned, no comprehensive national planning directives in Sweden; although the national authority for housing and planning has on behalf of the government produced a Vision for Sweden 2025 (Boverket 2012), it is more of an inspirational piece than a strategic national planning document. 
However, there is a national transport plan developed by the Swedish Transport Administration which is responsible for the national transport infrastructure. In turn, the regional authorities that are responsible for developing regional policy and the regional development programme are responsible for producing a county transport infrastructure plan through which the national funding for infrastructure is allocated. Transport planning is partly a separate system parallel to the spatial planning system, reflecting the sectoral organisation of Swedish governance in general, and the autonomous state agencies and municipalities and the decentralised planning system in particular. The responsibility for transport infrastructure is distributed among different institutions from the local to the national level, depending on several factors, for example, ownership of the roads, type of infrastructure and the daily operations and management of public transportation. However, although transport infrastructure planning and spatial planning are distinct in the institutional system they are intricately connected through territorial governance practices and in policy-making at the regional level.

In Sweden, according to the general findings of the ESPON COMPASS (2018) project, spatial planning is rather well coordinated with the policy field of transport infrastructure, i.e. there are visible efforts to align policies and measures at all policy levels (national, sub-national and local), but they are not integrated in terms of being targeted towards achieving similar policy goals. Spatial planning is also coordinated with cohesion and regional policy at the national and sub-national levels, but at local level spatial planning is only informed by regional and cohesion policies, which means that local spatial planning makes references to regional development programmes in for example planning and policy documents such as the comprehensive municipal plan, but without further efforts towards coordination or integration. In general, territorial impacts are comparatively well coordinated in Sweden horizontally, while the vertical relations are weaker. One reason is that the regional level is not able to absorb and channel the coordination of sector policies, either stemming from the national level or from the strong municipal level. However, another reason is the significant presence of the national state agency at sub-national level in the spatial planning system.

The regions are also important for the implementation of EU cohesion policy since in Sweden this is primarily related to regional development and growth issues. EU programmes (and EU-funded projects) are crucial in the implementation of cohesion policy but are organised in a variety of ways across Europe, and national, regional, transnational and cross-border programmes co-exist. The respective programming, management and monitoring arrangements form a complex and interrelated system of territorial governance. Sweden has adopted a centralised system of management for the national programmes but also with regionally decentralised management related to cross-border, transnational and interregional cooperation.

Overall, the general finding of the ESPON COMPASS (2018) project was that the EU discourse has had only moderate or little influence on Swedish territorial governance and spatial planning. Concepts and ideas in mainstream EU strategies (such as the Lisbon and Gothenburg strategies) have been included in domestic territorial governance and spatial planning documents but only with a partial impact in practice. For example, the EU 2020 strategy complies nicely with national approaches to regional development where growth and sustainability are at the centre but also seems to be applicable at the sub-national level. EU spatial policy documents have had little influence in practice. Although key concepts and ideas might be formally mentioned in spatial planning and territorial governance, they are not followed by any actual impact in practice. However, the European Spatial Development Perspective (CEC 1999) has without a doubt influenced the spatial development discourse in Sweden but other documents such as the Territorial Agenda 
have had less impact. However, all these documents have been noticed and, they have certainly shaped the mind-sets of some actors in Sweden, which can also be seen in some strategic documents at the regional level, for example in the discussion on polycentricity in the Stockholm region in the next section. So the impact has been rather on the cognitive level and by integrating various notions from these EU documents implicitly, without any direct reference.

\section{Stockholm: coordination through regional plans}

Stockholm metropolitan area has a population of about 2.3 million people. The administrative region consists of 26 municipalities. Stockholm municipality is the dominating municipality with about 40 percent of the region's total population. The Stockholm region has a long tradition of regional planning and is unique in Sweden in this regard, since it is the only region in Sweden that is obliged to do regional planning. Region Stockholm (former Stockholm County Council) is the regional planning authority that has the mandate to produce a statutory regional plan according to the Planning and Building Act. Regional planning should, according to the legislation, coordinate inter-municipal spatial concerns but the regional plan, even if statutory (i.e. produced under the law), is only a guiding document. Region Stockholm is thus dependent on the municipalities implementing the desired spatial development. However, the former Stockholm County Council was not the regional authority responsible for developing regional policy nor for producing a county transport infrastructure plan. But from 2019 the new Region Stockholm now also has this responsibility for regional development policy, which previously (prior to 2019) was the responsibility of the County Administrative Board of Stockholm, which represents the national state at the sub-national level. In this section, we will explore the coordination and integration between policy fields of spatial planning, transport infrastructure and regional development in the period before 2019 when the Stockholm County Council did not have the responsibility for regional development policy nor for producing a county transport infrastructure plan.

Stockholm is a monocentric region that is striving to become more polycentric. Transport infrastructure has been crucial for the spatial development of the Stockholm region, which to a large degree has developed along its main radial transport corridors (main roads and railway network) where the protection of the green wedges (i.e. preserving the green structure) has been strongly influential. This has created a monocentric region where most transport infrastructure is directed through the central core of the municipality of Stockholm. The monocentricity of the region has however also become a prominent planning challenge, not least in terms of congestion and infrastructure development. To combat this and urban sprawl, as well as to foster sustainable development the regional spatial objectives of planning have become focused on promoting polycentricity with several regional urban cores. This has been the spatial objective at least since the 1990s (see also Stockholm County Council 2003; 2010; 2018), that is, even before Sweden joined the EU in 1995.

Since the regional plan is only guiding, which imply that key issues for regional spatial planning in Stockholm are to pursue active cooperation across government, market and civil society actors, to coordinate decision-making and actions that have an impact on the quality of places. The most recent regional plans (Stockholm County Council 2003; 2010; 2018) are as such outcomes of dialogues and coordination with municipalities rather than being top-down strategies directly from Stockholm County Council. A polycentric Stockholm region is perhaps best understood as a regional spatial idea that also has begun to have an effect locally as some municipalities relate their comprehensive plans and planning projects in accordance with the regional cores defined 
in the regional plans, when suitable. There are additional barriers to implementing the spatial idea of polycentricity since for example, without involvement and investment from both public organisations and private actors such as developers, or investment by the state when it comes to infrastructure, the planning idea risks remaining just as an idea. A key issue for the region is thus to include and engage private actors and make them aware of the polycentric spatial strategy and communicate the regional cores as attractive sites for private investment. This regional spatial idea is therefore not merely dependent upon the coordination of public organisations (e.g. the municipalities) but also on the investment from private actors. Regional spatial planning is thus understood as a territorial governance practice of regional coordination activity and a policy arena where this is being coordinated, but how this is organised is also crucial, which becomes evident when considering the relations between two policy fields of spatial planning and transport infrastructure.

There are several public institutions involved in transport infrastructure in Sweden, and transport infrastructure might partly be seen as a parallel (planning) system (governed by different legislation) to the spatial planning system, which means that it is a challenging task to coordinate efforts between spatial planning and transport infrastructure development. However, there are some coordination issues between institutions at different levels and across different policy fields but also coordinating difficulties within organisations. Ideally, infrastructure policies or objectives could, according to the Swedish Traffic Administration, be used as means to achieve the spatial objectives of the region, and to some extent converge with the regional spatial objectives. It should however be recognised that these are two different types of plans with different rationalities and logics developed by two different agencies; transport infrastructure is developed when there is a need by the County Administrative Board, rather than steering the development as the intention is with the regional plan developed by the Stockholm County Council. The second coordination issue seems to be within Stockholm County Council, between the traffic office and the regional planning office, i.e. it concerns the organisation of infrastructure and spatial planning within the organisation. For example, the regional traffic office took the decision to reduce the frequency of commuter trains to a district that was strategically identified as a regional core by the regional planning office. In addition, the regional plan is customised to Stockholm's transport infrastructure plan rather than the opposite, and as such is dependent on it, especially with regard to its implementation. This means that regional planning in Stockholm can face difficulties in achieving its spatial objectives even at the planning stage as regional planning does not precede the county transport infrastructure plan. Both examples illustrate existing challenges faced by regional organisations in Stockholm in terms of policy coordination of spatial planning and transport infrastructure.

Furthermore, transport infrastructure is a policy field that is apparent on different government levels as well as important for other sectoral policy fields. It is a complex policy field as it involves daily operations and planning for public transportation, as well as investment in and implementation of transport infrastructure objects. In addition, it is a policy field with a strong vertical relation to the EU through different funds and programme (e.g. the TEN-T programme), which have rather limited impact on the spatial planning systems or territorial governance in general. The same applies here as with national and regional funds; the available European funds are not necessarily aligned with spatial objectives in the region. Yet these programmes and their co-funding are still useful to facilitate the implementation of some infrastructure projects. The importance of the EU, TEN-T and its financial resources has also been highlighted in a report by Stockholm County Council (2007). 
Spatial planning at the regional level, and regional development policy have on the other hand been not only coordinated but also integrated since the regional plan includes the regional development programme. Up until 2019, regional policy development was, as mentioned, the responsibility of the County Administrative Board of Stockholm, not Stockholm County Council which was responsible for regional planning. Regional planning and regional development have thus been institutionally separated from each other but in practice integrated since the regional development programme developed by the County Administrative Board, has been included in the regional plan developed by the county council.

In Stockholm, regional development is also the policy field with the most obvious vertical interaction between the EU and the region, which is highlighted in regional development policy documents produced by the county administrative board (e.g. County Administrative Board of Stockholm 2016) for example. These documents often include strategies developed as the regional counterpart to national or EU programmes and contain how the responsible regional organisations should work to achieve the formulated objectives in those documents. This example illustrates a straightforward vertical relation from the region to the EU and the Swedish Government in the policy field of regional development which aims to support the local economy. The county administrative board thus acts on behalf on the Swedish central government to develop programmes for regional development and to allocate economic resources for specific enterprises in various sectors. As noted on its website, the county administrative board receives state funding, though limited, each year from the Swedish central government which should be used to support the local economy and different types of enterprises to stimulate the long-term business and economic growth of the region (see County Administrative Board 2017).

The key role of regional planning seems to point out spatial objectives for the future, and to convey structural changes in the economy and how these potentially will affect the geographical structure. Regional development, spatial planning and transport infrastructure are related policy fields but are not necessarily integrated in the territorial governance practices in the region. Rather, regional spatial planning and regional development exist partly in parallel, especially in terms of cohesion policy. On the other hand there is coordination of spatial planning and regional development policy in key guiding documents for the spatial development of the region (i.e. the regional plan). Transport infrastructure planning is a complex policy field where the responsibility is distributed among several actors both vertically and horizontally from the regional organisations' perspectives.

Even though horizontal integration between two important regional documents, i.e. the regional development programme and the regional plan, has been the case, the challenges remain of coordinating the two other policy fields, transportation planning and spatial planning, despite the involvement of the same regional organisations. This demonstrates that integrating or coordinating policy fields organizationally is as important as coordination through document integration in order to achieve the spatial objectives outlined in the regional plan. In sum, spatial planning in Stockholm is a policy field that partly stands alone, separated from regional development and transport infrastructure, despite the horizontal document integration between the regional plan and the regional development programme. There are obviously relations between the policy fields, and the regional level functions as a policy arena where different policy fields such as transport infrastructure, regional development and spatial planning to some extent are coordinated. However, different plans and policy documents have different rationalities and logics, which among other things turn the coordinating activity, between the policy fields, into a challenging task, especially as it needs to be coordinated both between regional organisations and within them. 


\section{Östergötland: coordination through regional strategies}

Östergötland is a region in eastern Sweden, southwest of Stockholm (Fig. 1). The administrative region consists of 13 municipalities and has a total population of about 450000 (2017). The region has two core cities, Norrköping and Linköping, surrounded by smaller towns with different characters (Regionförbundet Östsam 2012). The organisation Region Östergötland was established in 2015 when Östergötland County Council was transformed into Region Östergötland. This was not only a change of name since it also included a significant institutional change when the mandate for regional development policy was transferred from a municipal and regional association to the directly elected regional authority (Hermelin \& Wänström 2017). The new Region Östergötland now has three main areas, or policy fields, of responsibility: healthcare, public transport, and regional development (including culture). Even if Region Östergötland has no statutory spatial planning mandate, in contrast to Region Stockholm which is obliged to conduct regional planning, spatial planning is integrated in many of the governance practices and considered as a tool for regional development (Hermelin \& Wänström 2017). At the regional level, the County Administrative Board of Östergötland, the national state representative, has the statuary position in relation to spatial planning with the responsibilities of governing and consulting the municipalities in their local planning processes and practices to make sure national provisions and areas of interest are considered and addressed properly. However, Region Östergötland also aims to guide and support the municipalities by providing them with important inputs and ideas for spatial planning at the local level, for example inputs to the municipal plans. This is further supported by the regional development and growth ordinance (SFS 2007:713), which states that regional development policies should take the spatial planning issues and the municipal comprehensive plans into account.

As stated above, spatial planning is considered as a way to implement regional development policies in Östergötland (Hermelin \& Wänström 2017). Spatial planning is thus integrated into regional development policy (and not vice versa), in which the latter is one of the main tasks of Region Östergötland. This is partly visible in the regional development programme, which focuses on economic growth in the entire region (Regionförbund Östsam 2012). The programme identifies six major challenges which are closely related to spatial planning. These challenges for example consist of attracting all types of people and enterprises to Östergötland, and ensuring good education for youths at the same time as elderly care is ensured despite issues with the population structure. Other identified challenges are for example related to promoting economic development and reducing the environmental footprint, where the economic cores (Norrköping and Linköping) may be strengthened at the same time as the outer region develops, based on their local assets, and thereby become better integrated into the main cores. As a consequence of the identified challenges and strategies in the regional development programme, Region Östergötland has also added a spatial perspective and has developed a non-statutory regional spatial strategy (Region Östergötland 2016a).

In the regional spatial strategy the regional development programme is translated into spatial planning at the regional level. An objective of the regional spatial strategy is to coordinate the regional development programme (Regionförbundet Östsam 2012) with the regional transport infrastructure plan (Region Östergötland 2014) and the spatial planning in the municipalities. In spite of being a non-statutory soft planning instrument, the regional spatial strategy coordinates different policy fields and is an important policy tool because it highlights spatial priorities, for example important spatial nodes and transport corridors. Adopting a spatial perspective 
on regional development has become a national policy and all Swedish regions must have a spatial perspective on regional development policy before 2020 according to Sweden's National Strategy for Sustainable Regional Growth and Attractiveness 2015-2020 (Government Offices of Sweden 2015). This is something that Region Östergötland has already started implementing, which is most obvious through a non-statutory regional spatial strategy. In Östergötland, the regional spatial strategy thus coordinates different policy fields in one document and highlights both the regional development programme and the two regional traffic plans as important documents that influence the preconditions of spatial planning in the region.

Spatial planning is thus an integral part of territorial governance practices of regional development in Östergötland, where it is intended to coordinate regional development policies and the transport infrastructure. However, spatial planning is conceived mainly as one tool or aspect of regional development policy; a policy field which also includes other less explicitly stated spatial regional development issues such as business support and rural development. These tasks, on the other hand, have a clear vertical relation to the EU and the national level, which in turn influences the local level through various forms of economic support, i.e. the region functions as an intermediary and coordinating actor.

An important task for Region Östergötland is to develop programmes that (as in Stockholm) are the regional counterparts to national and EU programmes. For example, the regional rural development programme contains means or tools that can be used to develop or stimulate the local development, local engagement, but also the local economy in terms of promoting enterprises and entrepreneurship in the countryside in Östergötland (Regionförbundet Östsam 2014). Agriculture is another example of a specific category of the local economy towards which economic means are directed, for example from the EU and through its funds (Regionförbundet Östsam 2014). In some cases, the region allocates funding through specific funds, even though several of them are channelled through national agencies through application procedures. For example, there is a regional service programme in Östergötland (Region Östergötland 2016b) which points to the importance of commercial (and public) services in the countryside, such as supermarkets, in order to keep the countryside attractive for residents and small businesses (see also Regionförbundet Östsam 2012). In this regard, the Swedish Agency for Economic and Regional Growth annually allocates funding which local actors can apply for (Region Östergötland 2016b).

Since Region Östergötland is also responsible for transport infrastructure and healthcare it can steer spatial development in the region through for example where it locates hospitals and health care facilities as well as bus routes and transport networks. For instance, the regional service programme highlights the organisation's responsibility for public transportation as an important tool to make targeted areas in the countryside more attractive for commercial services (Region Östergötland 2016b). In other words, public transportation is an instrument for spatial planning and public infrastructure which are prerequisites for regional development policies in the regional spatial strategy (Region Östergörland 2016a). Transportation and accessibility in the countryside are regarded as essential for making both the countryside and also urban areas more attractive. This illustrates the significant relation between transport infrastructure and regional development and that both are highly interrelated fields for the development of the region. In Östergötland these two policy fields are integrated in several important documents produced by Region Östergötland, showing that the regional level here acts as policy arena where the policy fields are coordinated. 
A significant difference when comparing the institutional structure for transport infrastructure in Östergötland in relation to Stockholm, is that in Östergötland the same regional organisation is responsible for both regional development and transport infrastructure (which was not the case in Stockholm until 2019), and can thus internally coordinate the two policy fields. Furthermore, Region Östergötland is responsible for both the county transport infrastructure plan and public transportation. This means that Region Östergötland, compared to Stockholm, is responsible for the county transport infrastructure plan through which the national funding for infrastructure is allocated, but also for the traffic provision programme that focuses on public transportation in coming years. In theory, at least, this means that Region Östergötland has the potential to coordinate the county transport infrastructure plan (an investment plan with available funding) with public transportation planning. Here, regional spatial planning and territorial governance play a key role:

"The intention of Region Östergötland is to develop strategies in collaboration with the municipalities that might function as support and guidance to incorporate the different plans and objectives into each of their respective planning documents and that all plans and objectives are consistent with an overall target. Through the strong link between the municipalities' comprehensive planning and the county transport infrastructure plan and the traffic provision programme, the municipalities and the Region are 'compelled to cooperate'." (Region Östergötland 2016a: 7, authors' translation).

In other words, the intention by the region is through processes that might be termed as territorial governance to coordinate these strategies with municipal spatial planning. This means that spatial planning has a significant role in coordinating policy fields such as transportation planning and regional development with municipal spatial planning. The key challenge in Östergötland lies in coordinating those issues with the municipalities and making sure that everyone is satisfied with the spatial objectives outlined in regional development strategies and in the regional spatial strategy. In Östergötland, as elsewhere in Sweden, the strong municipal self-government needs to be considered in the so-called coordinating activities which are being carried out with the region as the policy arena. And it is here that regional spatial planning seems to play a key role in Östergötland, i.e. in the activities where regional development and transport infrastructure are being coordinated, which needs to be done both within the regional organisation but, most importantly, horizontally with the municipalities since the region does not have a statutory planning instrument at hand.

\section{Conclusion}

Spatial planning, regional development and transport infrastructure are, in terms of institutional structure, distinct and separate policy fields in Sweden but not when the practices of territorial governance at regional level are considered. Regional development policy and spatial planning are governed by different types of legislation and national agencies. In Stockholm, regional development policy and spatial planning have also until recently been the responsibility of two different institutions; the directly elected Stockholm County Council (now Region Stockholm) and the central state authority at regional level - the county administrative board. However, regional development policy has partly been integrated into the statuary spatial regional plan, even if certain dimensions primarily related to EU funding and programmes have remained separate from spatial planning. Furthermore, even in Stockholm where there is a long tradition of regional planning, the statutory and mandatory regional plan is only advisory and thus dependent on other forms of territorial 
governance for its implementation and relevance. In Östergötland, which does not have the mandate to produce a statutory regional plan, spatial planning is perceived as on the one hand a tool for implementing regional development policies, and on the other hand as a vehicle to coordinate infrastructure transport and regional development issues.

On the other hand, transport infrastructure might be a potential spatial planning tool to steer spatial development that can be used by regional authorities that in Sweden have a limited number of formal spatial planning instruments at their disposal, but which are responsible for public transport. However, even if related, spatial planning and transport infrastructure policies seem to be distinctly different fields. In regard to transport infrastructure in Stockholm, coordination difficulties can be identified since both the county council and the county administrative board have had different responsibilities within the policy field, but there have also been other coordination difficulties within the organisations, which might still persist even if the regional reform (in 2019) harmonises responsibilities and the division of labour between institutions. In Östergötland the same organisation has since 2015 been responsible for transport infrastructure, regional development and spatial planning at the regional level. Furthermore, there are ambitions to integrate or at least coordinate these policy fields in the non-statutory regional strategy. The interrelations between regional development policy and spatial planning in Sweden are dynamic and it is a continuously evolving landscape, and the future effects of the most recent regional reform are still uncertain. There have in addition also been joint initiatives by the National Board of Housing, Building and Planning, and the Swedish Agency for Economic and Regional Growth to coordinate regional development programmes with municipal comprehensive plans, and also proposals for mandatory regional spatial plans (Smas et al. 2012).

Furthermore, the regions are arenas for horizontal coordination of local, sub-national, national and EU policies. There are few direct and obvious linkages between EU cohesion policy and spatial planning in Sweden but through different territorial governance practices EU policies and programmes as well as EU funded projects influence and impact spatial planning in Sweden. In addition, the EU discourse (e.g. concepts such as polycentricity and transport corridors) permeate various spatial planning documents and practices, and although the casual relationship between EU polices and spatial planning in Sweden is indecisive, EU programmes are important in different plans, practices and projects.

Regional planning, or perhaps rather, spatial planning at regional level, in Sweden is practised both through statutory planning and through soft planning mechanisms. The regional level in Sweden seems to function as an arena for multi-level coordination of different policy fields. The regions engage in territorial governance practices and assist in active cooperation across government, market and civil society to coordinate decision-making and actions that have an impact on the quality of places and their development. This is done through both statutory regional plans and non-statutory spatial strategies. Furthermore, even where there is a long-standing statutory regional planning tradition as in Stockholm, the planning practice and implementation of plans are dependent on coordinating actors and policy fields, as well as on mobilising local and private stakeholders. So even if the municipalities are still the prime spatial planning institutions in Sweden, spatial planning is also practised at the regional level. Both cases also illustrate difficulties not only of external coordination between different policy fields and institutions but also internally within regional authorities. In conclusion, it is thus argued that the organisation of territorial governance within a given institutional arrangement is crucial for how regions might function as multi-level coordination actors and as policy arenas of spatial planning, and needs to be investigated further. 


\section{References}

Boverket, 2011. Sammanställning av nationella mål, planer och program av betydelse för fysisk samhällsplanering. Rapport 2011, 7. Karlskrona: Boverket, https://www.boverket.se/globalassets/ publikationer/dokument/2011/sammanstallning-mal-planer.pdf. [26 November 2018].

Boverket, 2012. Vision för Sverige 2025. Karlskrona: Boverket, https://www.boverket.se/globalassets/ publikationer/dokument/2012/vision-for-sverige-2025.pdf. [26 November 2018].

Boverket, 2014. Regionalisering av nationella mål, planer och program. Rapport 2014, 10. Karlskrona: Boverket, https://www.boverket.se/globalassets/publikationer/dokument/2014/regionaliseri-g-avnationella-mal-planer-och-program.pdf. [26 November 2018].

Böhme K., 2002. Nordic Echoes of European Spatial Planning: Discursive Integration in Practice. Stockholm: Nordregio.

CEC, 1997. The EU Compendium of Spatial Planning Systems and Policies. Regional Development Studies. Luxemburg: Commission of the European Communities.

CEC, 1999. European Spatial Development Perspective: Towards Balanced and Sustainable Development of the Territory of the European Union. Luxemburg: Commission of the European Communities, http://ec.europa.eu/regional_policy/sources/docoffic/official/reports/pdf/sum_en.pdf. [20 February 2018].

County Administrative Board, 2012. Infrastrukturens och bostädernas betydelse för innovation och tillväxt i Stockholmsregionen. Länsstyrelsen Stockholm, http://www.lansstyrelsen.se/stockholm/ SiteCollectionDocuments/Sv/publikationer/2012/rapport-2012-17.pdf [17 October 2017].

County Administrative Board of Stockholm, 2016. Regional handlingsplan för landsbygdsprogrammet och havs- och fiskeriprogrammet 2014-2020. Länsstyrelsen Stockholm, https://www. lansstyrelsen.se/stockholm/tjanster/publikationer/2016/regional-handlingsplan-for-landsbygdsprogrammet-och-havs--och-fiskeriprogrammet-2014-2020.html [26 November 2018].

County Administrative Board of Stockholm, 2017. Länsstyrelsen Stockholm. http://www.lansstyrelsen. se/stockholm/ [18 October 2017].

ESPON COMPASS, 2018. Comparative Analysis of Territorial Governance and Spatial Planning Systems in Europe. https://www.espon.eu.planning-systems [26 November 2018].

Galland D., 2012. Understanding the Reorientations and Roles of Spatial Planning: The Case of National Planning Policy in Denmark. European Planning Studies, vol. 20, no. 8, pp. 1359-1392.

Government Offices of Sweden, 2015. En nationell strategi för regional konkurrenskraft, entreprenörskap och sysselsättning 2015-2020. Regeringskansliet, https://www.regeringen.se/ contentassets/98919a0ca0f1427491a3eef22a7d177c/en-nationell-strategi-for-hallbar-regional-tillvaxt-och-attraktionskraft-20152020.pdf [26 November 2018].

Hammarlund K. G., 2004. Regional reform and citizen participation in Sweden. Innovation, vol. 17, no. 2, pp. 145-164.

Hanssen G. S., Mydske P. K., Dahle E., 2013. Multi-level coordination of climate change adaptation: by national hierarchical steering or by regional network governance? The International Journal of Justice and Sustainability, vol. 18, no. 8, pp. 869-887.

Hermelin B., Smas L., 2010. Knowledge Dynamics in the Stockholm Region: A study of KIBS, ICT and Medtech. Stockholm: Stockholm University.

Hermelin B., Wänström J., 2017. Att organisera för regional utveckling - Erfarenheter från regionbildning i Östergötland. Linköping: Linköpings universitet.

Hovik S., Stokke K. B., 2007. Network Governance and Policy Integration - the Case of Regional Coastal Zone Planning in Norway. European Planning Studies, vol. 15, no. 7, pp. 927-944.

Lidström A., 2013. Citizens in the City-Regions Political Orientations across Municipal Borders. Urban Affairs Review, vol. 49. no. 2, pp. 282-306.

Nadin V., Stead D., 2008. European Spatial Planning Systems, Social Models and Learning. disP -The Planning Review, vol. 44, no. 172, pp. 35-47. 
Neuman M., 2007. Multi-Scalar Large Institutional Networks in Regional Planning. Planning Theory \& Practice, vol. 8, no. 3, pp. 319-344.

Neuman M., Zonneveld W., 2018. The resurgence of regional design. European Planning Studies, vol. 26, no. 7, pp. 1297-1311.

Newman P., Thornley A., 1996. Urban Planning in Europe: International Competition, National Systems and Planning Projects. London: Routledge.

Pollitt C., Talbot C., Caulfield J., Smullen A., 2005. Agencies. London: Palgrave Macmillan UK.

Purkarthofer E., 2016. When soft planning and hard planning meet: Conceptualising the encounter of European, national and sub-national planning. European Journal of Spatial Development, no. 61, pp. 1-20.

Region Östergötland, 2014. Länsplan för regional transportinfrastruktur 20142025. Region Östergötland, https://www.regionostergotland.se/Regional-utveckling/Samhallsplanering/Infrastruktur/ [23 August 2017].

Region Östergötland, 2016a. Regional strukturbild - för Östergötland. Region Östergötland, https:// wssext.regionostergotland.se/regsam/Samh\%C3\%A4llsbyggnad/Fysisk\%20planering/Regional\%20 strukturbild\%20f\%C3\%B6r\%20\%C3\%96sterg\%C3\%B6tland\%20beslutat\%202016\%2012.pdf [26 November 2018].

Region Östergötland, 2016b. Regionalt serviceprogram: Östergötlands län 2014-2020. Region Östergötland, https://wssext.regionostergotland.se/regsam/Samh\%C3\%A4llsbyggnad/Landsbygd\%20och\%20sk\%C3\%A4rg\%C3\%A5rd/Regionalt\%20serviceprogram\%20f\%C3\%B6r\%20 \%C3\%96sterg\%C3\%B6tland\%202014-2018\%20antagen\%202016.pdf [26 November 2018].

Region Östergötland, 2018. Region Östergötland, https://www.regionostergotland.se/ [26 November 2018].

Regionförbundet Östsam, 2012. Regionalt utvecklingsprogram för Östergötland 2030. Östsams fullmäktige, https://wssext.regionostergotland.se/regsam/Samh\%C3\%A4llsbyggnad/RUP\%202030_ webprint.pdf [26 November 2018].

RegionförbundetÖstsam,2014.Insatsprogram Landsbygd2014-2020.Östsamsfullmäktige, https://wssext. regionostergotland.se/regsam/Samh\%C3\%A4llsbyggnad/Landsbygd\%20och\%20sk\%C3\%A4rg\%C3\% A5rd/Insatsprogram\%20Landsbygd\%202014-2020.pdf [26 November 2018].

Røiseland A., Hofstad H., Lidström A., \& Sørensen E., 2015. Taking Stock of Regional Governance in Nordic Countries. Scandinavian Journal of Public Administration, vol. 19, no. 4, pp. 3-6.

Schmitt P., 2015. Sweden. disP - The Planning Review, vol. 51, no. 1, pp. 72-73.

Schmitt P., Smas L., 2018. Spatial planning in Sweden: Key notions, trajectories and challenges. [in:] J. Farinós Dasí \& J. Peiró (eds.) Territorio y Estados: Elementos Para La Coordinación de Las Políticas De Ordenación Del Territorio En El Siglo Xxi [Territory and States: Essentials for the Coordination of Spatial Planning Policies in the XXIst Century], Valencia: Tirant Humanidades, pp. 597-620.

Schmitt P., Smas L., 2019. Shifting Political Conditions for Spatial Planning in the Nordic Countries. [in:] A. Eraydin \& K. Frey (eds.), Politics and Conflict in Governance and Planning: Theory and Practice, New York: Routledge, pp. 133-150.

SFS 1998:808. Miljöbalken. [The Environmental Code].

SFS 2007:713. Förordning om regionalt tillväxtarbete. [The Regional Growth Ordinance].

SFS 2010:900. Plan och bygglagen [The Planning and Building Act].

Smas L., Damsgaard O., Fredricsson C., Perjo L. 2012. Integrering av översiktsplanering och regionalt tillväxtarbete: Nordiska och europeiska utblickar. Nordregio Working Paper 2012: 5. Stockholm: Nordregio.

Stockholm County Council, 2003. Regional utvecklingsplan för Stockholmsregionen. Stockholms läns landsting, http://www.rufs.se/globalassets/d.-rufs-2010/rufs-2010-planen/rufs_2001_hela.pdf [26 November 2018].

Stockholm County Council, 2007. Transeuropeiska transportnätverk(TEN-T) i Stockholm Mälarregionen. Rapport 15:2007. Stockholms läns landsting, http://www.rufs.se/globalassets/h.-publikationer/2007-15_r_transeuropeiska_transportnatverk.pdf [26 November 2018]. 
Stockholm County Council, 2010. Regional utvecklingsplan för Stockholmsregionen 2010. Stockholms läns landsting, http://rufs.se/globalassets/d.-rufs-2010/rufs-2010-planen/rufs10_hela.pdf [26 November 2018].

Stockholm County Council, 2018. Regional utvecklingsplan för Stockholmsregionen 2050. Stockholms län landsting, http://www.rufs.se/rufs-2050 [26 November 2018].

van Well L., Schmitt P., 2016. Territorial governance across Europe: Setting the stage. [in:] P. Schmitt \& L. Van Well (eds.) Territorial governance across Europe: Pathways, Practices and Prospects. Routledge: London, pp. 3-20. 